\title{
Efficiency of Forage Harvest by Grazing Cattle
}

\author{
C.D. ALLISON, M.M. KOTHMANN, AND L.R. RITTENHOUSE
}

\section{Abstract}

Three grazing trials of 14 days each were conducted in April, July, and September, 1977, to examine the effects of grazing pressure on forage disappearance, organic matter intake, and the relationship between intake and forage disappearance. Levels of grazing pressure studied were $10,20,40$, and $50 \mathrm{~kg}$ of forage allowed per animal-unit per day $(\mathrm{kg} / \mathrm{au} / \mathrm{da})$. Standing crop was measured before, during the middle, and immediately after each trial. Organic matter intake was estimated at the beginning and end of each trial by the fecal excretion:indigestibility ratio technique. Total standing crop declined steadily during the grazing trials, with forage availability being significantly less at the end than at the beginning or middle of the trials. Averaged over the three trials, total forage disappearance during a 14-da grazing period was 236, 334,355 , and $457 \mathrm{~kg}$ per pasture and forage losses per au per day were $8.5,12.0,12.7$, and $16.3 \mathrm{~kg}$ for the $10,20,40$, and $50 \mathrm{~kg} / \mathrm{au} / \mathrm{da}$ grazing pressures, respectively. However, daily intake averaged across all treatments, periods, and trials was approximately 9 $\mathrm{kg} / \mathrm{au} / \mathrm{da}$. At the grazing pressure level of $10 \mathrm{~kg} / \mathrm{au} / \mathrm{da}$, forage disappearance approximated the average daily intake, whereas, grazing pressures of 20,40 , and $50 \mathrm{~kg} / \mathrm{au} / \mathrm{da}$ had forage disappearances that exceeded intake by 28,48 , and $90 \%$, respectively. These data indicate a possibility for a two-fold increase in the efficiency of forage harvest by grazing cattle as grazing pressure is increased.

Harvesting forage before and after grazing has been used for estimating the quantity of forage consumed by grazing animals. This method assumes that forage consumption is equivalent to the difference in standing crop of forage determined before and after grazing. It is most applicable to short grazing periods in order to minimize sources of error such as: forage growth during grazing; unrecoverable reject; unaccountable depressing or stimulating effects of the animals on grazed forage yield; and unmeasured use of nutrients by the animals (Carter et al. 1960, McNaughton 1979).

Range herbage disappearance may be proportional to, but is greater than, forage consumption by livestock because of herbage losses such as those resulting from weathering and trampling (Laycock et al. 1972). Forage consumed by insects and rodents (Van Dyne and Meyer 1964, Hewitt et al. 1976; Pearson 1975) also biases estimates of forage consumed by grazing animals upward when measured by forage disappearance.

Laycock et al. (1972) reported intake estimates were up to three times higher when comparing paired, clipped plots with fecal excretion:indigestibility ratio techniques. Higher intake estimates obtained from clipping were attributed to trampling losses and "invisible" utilization.

Gordon et al. (1966) stated that as grazing pressure was increased, cattle consumed more of the available forage. These

\footnotetext{
Authors are Extension range management specialist, New Mexico State Univ: professor, Texas Agr. Exp. Sta.; and associate professor, Colorado State Univ. Allison's present address is Box 3AF. New Mexico State Univ., Las Cruces; Kothmann's present address is Dep. Range Science, Texas A\&M Univ., College Station; Rittenhouse's present address is Dep. Range Science, Colorado State Univ., Fort Collins.

This report is Technical Article No. 16183 from the Texas Agr. Exp. Sta.

The authors would like to thank Mr. Robert Gordon and Mr. James Bluntzer for assisting in the collection of the data for this study.

Manuscript received July 21. 1980
}

data were not actual consumption, but rather forage disappearance as measured before and after a grazing period. Average grazing pressures of $11.1,16.2$, and $21.9 \mathrm{~kg}$ of forage per cow per day resulted in dry matter disappearance values of 10.6, 13.4, and $15.0 \mathrm{~kg}$ of forage per cow per day, respectively. It can be seen from this research that forage losses for the most intensive grazing pressure level $(11.1 \mathrm{~kg}$ per cow per day) closely approximate expected dry matter intake of the cows.

The objective of this study was to evaluate and compare forage disappearance and forage intake of cattle under four levels of grazing pressure on a Stipa-Bouteloua mixed grass prairie in North-Central Texas.

\section{Study Area}

Field research for this study was conducted on the Texas Experimental Ranch near Throckmorton, Texas, during 1977. The study area is part of the Rolling Plains vegetation region which comprises approximately 6.3 million ha of rolling to rough topography.

Average frost-free period is $220 \mathrm{da}$, with peak periods of forage production occurring in April, May, June, and September. Average annual precipitation, over a 50 -year record, is $65.6 \mathrm{~cm}$. Measured precipitation at the study area during 1977 was $53.8 \mathrm{~cm}$.

Perennial grasses usually comprise over $80 \%$ of the vegetation with less than $10 \%$ annual grasses and approximately $10 \%$ forbs. Three species, sideoats grama [Bouteloua curtipendula (Michx. Torr.)], Texas wintergrass (Stipa leucotricha Trin. \& Rupr.), and buffalograss [Buchloe dactyloides (Nutt) Engelm], generally account for over $70 \%$ of the ranch vegetation (Kothmann et al. 1970).

\section{Experimental Procedure}

Intake, dietary chemical and botanical components, and standing crop changes were monitored under four levels of grazing pressure. The definition of grazing pressure as used in this paper is: "the mean weight of forage allowed per animal-unit-day for a relatively short grazing period of specified length" (Society for Range Management 1974).

Levels of grazing pressure monitored were $10,20,40$, and $50 \mathrm{~kg}$ of forage per animal-unit-day $(\mathrm{kg} / \mathrm{au} / \mathrm{da})$ for a 14-da grazing trial. Grazing pressures were created by varying pasture size with electric fences on an area with a relatively uniform standing crop of vegetation.

Three separate 14-da trials were conducted during 1977. Trial I was in April (4-5-77 through 4-18-77), Trial II was in July (7-5-77 through 7-18-77), and Trial III was from mid-September to early October (9-20-77 through 10-2-77). Trials were conducted at these times to evaluate the effects of changes in chemical composition of forage, phenology of plant species, and physiological status of the cows upon forage intake and disappearance. Trial 1 was conducted when Texas wintergrass was growing rapidly, warm-season grasses had not yet begun rapid growth, and cows were in hcavy lactation. Trial II was initiated when Texas wintergrass was mature, warmseason grasses were growing, and cows were dry and pregnant. 
Trial Ill was conducted when Texas wintergrass was dormant, warm-season grasses were maturing, and cows were in late gestation

Each trial was conducted on a different area in order to prevent treatment effects of a previous trial from confounding results of subsequent trials. All trials, however, were conducted on a Clay Loam range site. The four grazing pressure treatments were replicated twice in all three trials.

Sixteen animals, eight cows with established esophageal fistulae and eight intact 4-year-old Hereford cows were used during each trial. Animals were randomly assigned at the initiation of each trial with one esophageally fistulated cow for diet collections and one intact cow for total fecal collections within each of the two replications per treatment. The same animals were used in all three trials.

Due to the limited number of animals per treatment, a preliminary intake trial, designated as a "covariate trial", was conducted. This covariate trial included two consecutive days of diet collection with esophageally fistulated cows and four consecutive days of total fecal collection. This trial was conducted 1 week prior to initiation of each of the three grazing pressure trials. Intake estimates for individual cows during this trial were used to adjust their intake data from the grazing pressure trials using analysis of covariance procedures.

\section{Standing Crop}

Standing crop estimates of range vegetation were made by hand clipping vegetation rooted within plots $1 \mathrm{~m}^{2}$. Vegetation was clipped to a height of $1 \mathrm{~cm}$ or less. Time and labor restrictions limited the number of plots that could be clipped to five in each treatment of each replication.

Plants we re separated in the field during clipping and placed into one of the following three categories: (1) cool-season grasses; (2) warm-season grasses; and (3) forbs. Cool-season grasses were comprised of Texas wintergrass and Japanese brome (Bromus japonicus Thurb.). Warm-season grasses included mostly sideoats grama and buffalograss. The major components of the forb category were heath aster (Aster ericoides L.) and western ragweed (Ambrosia psilostachya DC.).

Vegetation was dried at $60^{\circ} \mathrm{C}$ for 48 hours and weighed to the nearest $0.1 \mathrm{~g}$. These measurements were converted and expressed as $\mathrm{kg} /$ ha. Confidence intervals $(P=.05)$ were computed for each of the three categories and for the total standing crop.

Standing crop estimates were conducted three times for each of the three trials. Plots were clipped approximately 2 weeks prior to placing animals within the trial area. This estimate of standing crop also served as a basis from which pasture sizes of the four grazing pressure treatments were calculated. A second set of plots was clipped immediately after the first 3-da fecal collection which coincided with day five of each 14-da trial. The third clipping immediately followed the second 3-da fecal collection which was day 15 of each trial.

\section{Intake Determination}

Organic matter intake of cattle was estimated by the fecal excretion:indigestibility ratio technique:

$$
\text { intake }=\frac{\text { fecal output }}{\text { 1-DOM }}
$$

where,

$$
\begin{aligned}
\text { intake } & =\text { organic matter }(\mathrm{g}) \\
\text { fecal output } & =\text { organic matter }(\mathrm{g}) \\
\text { DOM } & =\text { digestible organic matter coefficient. }
\end{aligned}
$$

Fecal output was measured by total fecal collection procedures similar to those discussed by Kartchner and Rittenhouse (1979). The indigestibility of organic matter in the diet was determined by in vitro techniques employing a 48-hour fermentation of samples with rumen liquor obtained from a steer on an all-roughage diet (Tilley and Terry 1963) followed by neut ral detergent fiber (NDF) extraction (Van Soest and Wine 1967). In vitro values were corrected using a standard forage of known in vivo digestibility which was included in each batch analysis.
Significant treatment differences for standing crop and organic matter intake of cows were determined by analysis of variance. Mean separation was conducted by Duncan's new multiple range test (Steel and Torrie 1960). Due to the unbalanced nature of the data, a computerized general linear models program of Barr et al. (1976) was used for the analysis of variance.

\section{Results and Discussion}

Forage availability reached a maximum of $2,222 \mathrm{~kg} / \mathrm{ha}$ (Table 1) during July, when averaged across all levels of grazing pressure and periods within trials. Total above-ground herbaceous standing crop estimates during April (Trial I) and September (Trial III) were significantly lower than values estimated for July. Cool-season grasses comprised the largest proportion of standing crop during April $(63 \%)$ but had declined to $30 \%$ in September. Warm-season grasses increased significantly during the growing season, reaching a maximum of $1,095 \mathrm{~kg} / \mathrm{ha}$ during September, which was significantly higher than amounts for April and July. Forbs, likewise, increased with season of year, reaching a high of $278 \mathrm{~kg}$ / ha during September (Table 1).

Table 1. Mean standing crop $(\mathrm{kg} / \mathrm{ha})$ for three trials averaged across treatments, replicates, and periods.

\begin{tabular}{lccc}
\hline \hline & \multicolumn{3}{c}{ Trial } \\
\cline { 2 - 4 } & Apr. & July & Sept. \\
\hline Cool-season grasses & $861^{\mathrm{bl}}$ & $1307^{\mathrm{a}}$ & $576^{\mathrm{c}}$ \\
Warm-season grasses & 465 & $728^{\mathrm{b}}$ & $1095^{\mathrm{a}}$ \\
Forbs & $27^{\mathrm{c}}$ & $187^{\mathrm{b}}$ & $278^{\mathrm{a}}$ \\
Total & $1353^{\mathrm{c}}$ & $2222^{\mathrm{a}}$ & $1949^{\mathrm{b}}$ \\
\hline
\end{tabular}

${ }^{1 \mathrm{abc}}$ Means in the same row with a common superscript are not significantly different at the .05 level of probability.

Total standing crop, ave raged across trials, was not significantly different in the 40 and $50 \mathrm{~kg} / \mathrm{au} /$ da treatments; however, standing crop was significantly lower in the 20 and $10 \mathrm{~kg} / \mathrm{au} / \mathrm{da}$ treatments (Table 2). Cool-season and warm-sea son grasses were significantly lower in the 10 and $20 \mathrm{~kg} / \mathrm{au} / \mathrm{da}$ grazing pressure treatments than in the 40 and $50 \mathrm{~kg} / \mathrm{au} / \mathrm{da}$ treatments. The composition of forbs was approximately equal for all treatments.

Table 2. Mean standing crop ( $\mathrm{kg} / \mathrm{ha})$ for four levels of grazing pressure.

\begin{tabular}{lcccc}
\hline \hline & \multicolumn{4}{c}{ Grazing pressure } \\
\cline { 2 - 5 } & 10 & 20 & 40 & 50 \\
\hline Cool-season grasses & $733^{\mathrm{c}}$ & $829^{\mathrm{bc}}$ & $1025^{\mathrm{a}}$ & $979^{\mathrm{ab}}$ \\
Warm-season grasses & $620^{\mathrm{b}}$ & $662^{\mathrm{b}}$ & $750^{\mathrm{ab}}$ & $862^{\mathrm{a}}$ \\
Forbs & $168^{\mathrm{a}}$ & $194^{\mathrm{a}}$ & $148^{\mathrm{a}}$ & $179^{\mathrm{a}}$ \\
Totals & $1521^{\mathrm{c}}$ & $1685^{\mathrm{b}}$ & $1923^{\mathrm{a}}$ & $2020^{\mathrm{a}}$ \\
\hline
\end{tabular}

'Grazing pressure levels are $10,20,40$, and $50 \mathrm{~kg}$ forage allowed per animal-unit per 2abed.

${ }^{2 a b c d}$ Means in the same row with a common superscript are not significantly different at the .05 level of probability.

Total standing crop and standing crop of cool-season grasses declined steadily during the trials, with forage availability being significantly less at the end of the 14-da trials than at the beginning or middle (Table 3 ). Standing crops of both warm-season grasses and forbs were significantly lower at the end of a trial than at the beginning, but they followed different trends for disappearance. Standing crop of warm-season grasses declined significantly to the middle of the trial but did not decline significantly from the middle to the end of a trial. Standing crop of forbs did not differ between the beginning and middle of a trial, but was significantly less at the end of a trial (Table 3).

Cool-season grasses were highly preferred in April but in July and September, they were utilized more heavily during the last 7 days than during the first 7 days. During July and September, 
Table 3. Mean standing crop (kg/ha) for three periods within a trial.

\begin{tabular}{lccc}
\hline \hline & \multicolumn{3}{c}{ Period $^{1}$} \\
\cline { 2 - 4 } & 1 & 2 & 3 \\
\hline Cool-season grasses & $1140^{\mathrm{a} 2}$ & $811^{\mathrm{b}}$ & $597^{\mathrm{c}}$ \\
Warm-season grasses & $968^{\mathrm{a}}$ & $644^{\mathrm{b}}$ & $522^{\mathrm{b}}$ \\
Forbs & $187^{\mathrm{a}}$ & $192^{\mathrm{a}}$ & $107^{\mathrm{b}}$ \\
Total & $2293^{\mathrm{a}}$ & $1647^{\mathrm{b}}$ & $1226^{\mathrm{c}}$ \\
\hline
\end{tabular}

1 Periods 1,2 , and 3 correspond to days 1,7 , and 14 of a 14-day grazing trial. ${ }^{2 a b c}$ Means in the same row with a common superscript are not significantly different at the .05 level of probability.

cattle preferred warm-season grasses initially in a trial, but as a trial progressed, forbs were utilized more. Presumably, cattle selected warm-season grass leaf material first, shifting selection to forbs once grass leaf material declined in the standing crop to a point where stems accounted for a major portion of warm-season grass standing crop.

Figure 1 illustrates the forage disappearance trends for the four treatments, averaged across the three trials. All grazing pressures resulted in a linear decline in forage availability during the trials. The rate of forage disappearance within a treatment increased as the total amount of forage available in the pasture increased.

\section{Forage Disappearance within Trials and Treatments}

Forage disappearance trends were similar in all three trials within the respective treatments (Table 4 ). When averaged over the three trials, forage disappearance between the beginning and end of the 14-da trials was $236,334,355$, and $457 \mathrm{~kg}$ per pasture for the $10,20,40$, and $50 \mathrm{~kg} / \mathrm{au} / \mathrm{da}$ treatments, respectively (Table 5).

Table 5. Forage disappearance ( $\mathrm{kg} /$ pasture) from the beginning to the end of three trials for four levels of grazing pressure.

\begin{tabular}{ccccc}
\hline \hline & \multicolumn{4}{c}{$\begin{array}{c}\text { Forage disappearance } \\
\text { (kg/pasture) }\end{array}$} \\
\cline { 2 - 5 } $\begin{array}{c}\text { Grazing pressure } \\
\text { (kg/au/da) }\end{array}$ & Apr. & July & Sept. & $\bar{x}$ \\
\hline 10 & 202 & 247 & 257 & 236 \\
20 & 297 & 378 & 322 & 334 \\
40 & 265 & 309 & 483 & 355 \\
50 & 466 & 397 & 496 & 457 \\
\hline
\end{tabular}

When these values are expressed on a disappearance per animalunit per day basis, they become $8.5,12.0,12.7$, and $16.3 \mathrm{~kg} / \mathrm{au} / \mathrm{da}$ for the $10,20,40$, and $50 \mathrm{~kg} / \mathrm{au} / \mathrm{da}$ treatments, respectively (Table 6). Data such as these have been interpreted by some resea rchers to indicate that a greater amount of forage was consumed under

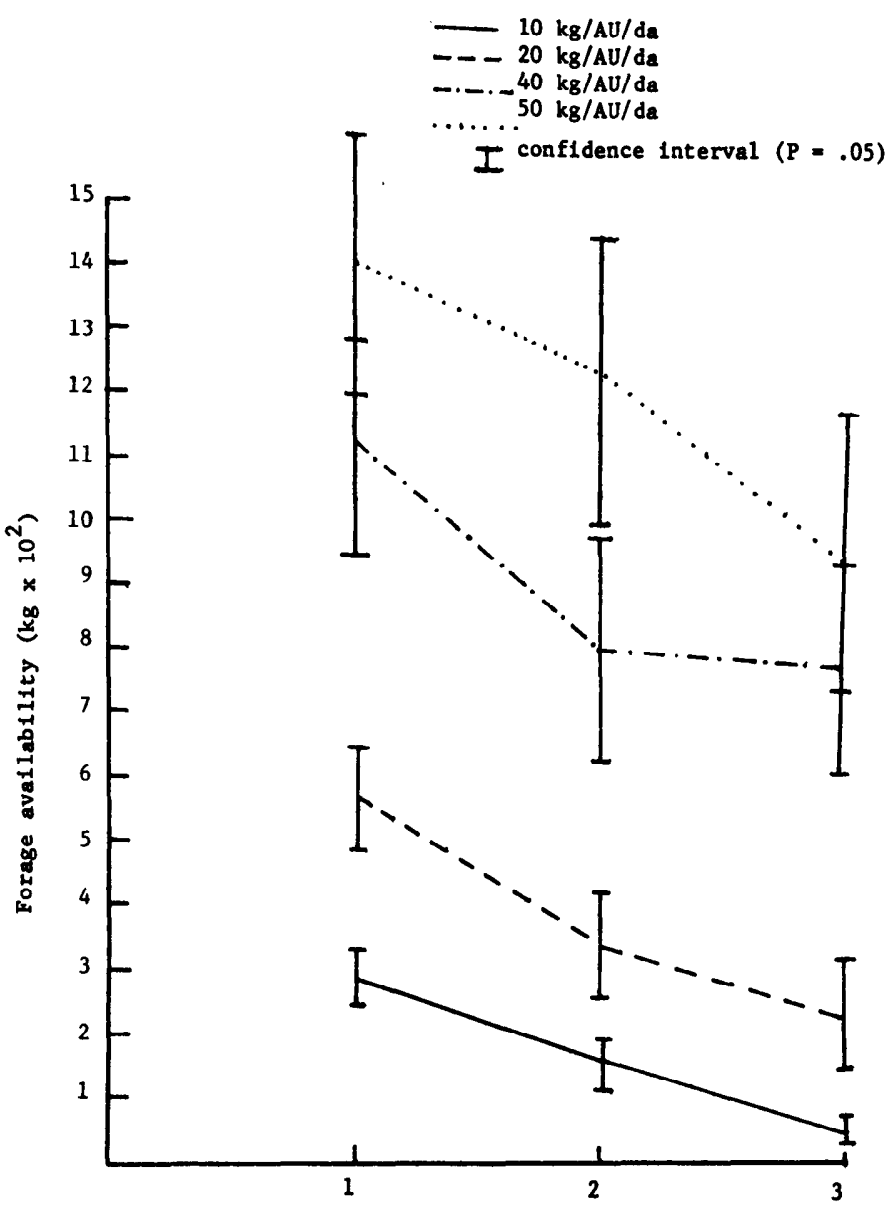

Pertod

Fig. 1. Mean forage availability per pasture for four levels of grazing pressure (kg/au/da) at three periods averaged across Trials 1,2 , and 3 .

lighter grazing pressures. However, when intake values are examined (Table 6), it is seen that average daily intake was approximately equal for all four treatments. Estimated intake accounted for $99 \%$ of forage disappearance at the $10 \mathrm{~kg} / \mathrm{au} / \mathrm{da}$ grazing pressure (Table 6). At grazing pressures of 20,40 , and $50 \mathrm{~kg} / \mathrm{au} / \mathrm{da}$, the efficiencies of forage utilization (intake $\div$ disappearance $\times 100$ ) were 78,68 , and $53 \%$, respectively (Table 6 ). These data support those of Gordon et al. (1966) and indicate the possibility for greater

Table 4. Mean herbaceous standing crop ( $\mathrm{kg} /$ pasture) and confidence intervals $(P=.05)$ for three trials, four levels of grazing pressure and three periods within a trial, averaged across two replications.

\begin{tabular}{|c|c|c|c|c|c|c|c|c|c|c|c|c|}
\hline \multirow{2}{*}{$\begin{array}{l}\text { Grazing } \\
\text { pressure } \\
\text { Period }^{2}\end{array}$} & \multicolumn{3}{|c|}{10} & \multicolumn{3}{|c|}{20} & \multicolumn{3}{|c|}{40} & \multicolumn{3}{|c|}{50} \\
\hline & 1 & 2 & 3 & 1 & 2 & 3 & 1 & 2 & 3 & 1 & 2 & 3 \\
\hline & \multicolumn{12}{|c|}{ Trial $1^{3}$} \\
\hline & $278 \pm 46$ & $147 \pm 32$ & $76 \pm 51$ & $556 \pm 93$ & $348 \pm 93$ & $259 \pm 108$ & $1111 \pm 185$ & $784 \pm 230$ & $846 \pm 216$ & $1389 \pm 232$ & $1219 \pm 262$ & $923 \pm 210$ \\
\hline \multicolumn{13}{|c|}{ Trial 2} \\
\hline & $280 \pm 28$ & $169 \pm 34$ & $33 \pm 16$ & $560 \pm 57$ & $270 \pm \overline{73}$ & $182 \pm 66$ & $1120 \pm 114$ & $867 \pm 147$ & $811 \pm 131$ & $1400 \pm 142$ & $1254 \pm 114$ & $1003 \pm 227$ \\
\hline \multicolumn{13}{|c|}{ Trial 3} \\
\hline & $280 \pm 49$ & $143 \pm 38$ & $23 \pm 6$ & $560 \pm 98$ & $378 \pm 100$ & $238 \pm 74$ & $1120 \pm 196$ & $733 \pm 186$ & $637 \pm 146$ & $1400 \pm 245$ & $1204 \pm 284$ & $904 \pm 217$ \\
\hline \multicolumn{13}{|c|}{$\bar{x}$ Trials 1,2 , and 3} \\
\hline & $280 \pm 41$ & $153 \pm 35$ & $44 \pm 24$ & $560 \pm 83$ & $332 \pm 89$ & $226 \pm 83$ & $1120 \pm 165$ & $795 \pm 188$ & $765 \pm 164$ & $1400 \pm 206$ & $1226 \pm 220$ & $943 \pm 218$ \\
\hline
\end{tabular}

'Grazing pressure levels are expressed as $10,20,40$, and $50 \mathrm{~kg}$ forage available per animal-unit per day.

2Periods, 1, 2, and 3 correspond to days 1, 7, and 15 of a 14-da grazing trial, respectively.

3 Trials 1, 2, and 3 correspond to April, July, and September, 1977, respectively. 
Table 6. Average forage disappearance and organic matter intake for four levels of grazing pressure averaged across three trials and two periods within each trial.

\begin{tabular}{cccc}
\hline \hline $\begin{array}{l}\text { Grazing pressure } \\
(\mathrm{kg} / \mathrm{au} / \mathrm{da})\end{array}$ & $\begin{array}{c}\text { Intake' } \\
(\mathrm{kg} / \mathrm{au} / \mathrm{da})\end{array}$ & $\begin{array}{c}\text { Forage } \\
\text { disappearance } \\
(\mathrm{kg} / \mathrm{au} / \mathrm{da})\end{array}$ & $\begin{array}{c}\text { Efficiency33 } \\
(\%)\end{array}$ \\
\hline 10 & 8.4 & 8.5 & 99 \\
20 & 9.4 & 12.0 & 78 \\
40 & 8.6 & 12.7 & 68 \\
50 & 8.6 & 16.3 & 53
\end{tabular}

Intake values are expressed as oven-dry organic matter.

'Forage disappearance values are expressed as air-dry dry matter.

${ }^{3}($ Intake $\div$ forage disappearance $) \times 100$.

efficiency of forage harvesting as grazing pressure becomes more intense. With more intensive grazing pressures, produced by greater stocking densities, more of the forage disappearance fraction can be attributed to consumption by grazing animals, thus reducing the "invisible" utilization reported by Laycock et al. (1972).

This phenomenon of increasing the harvesting efficiency of grazing animals by increasing the grazing pressure may play a role in the reported successes of short duration grazing systems (Savory and Parsons 1980). Short duration grazing systems entail high stocking densities in combination with short grazing periods and optimal grazing pressure (a function of stocking density and length of grazing period). More research and a re-examination of past research data are needed to study this harvesting efficiency by grazing animals and the effects short duration grazing systems have on this efficiency.

\section{Conclusions}

Total forage availability declined significantly during the 14-day grazing trials under all grazing pressure treatments. Forage disappearance per pasture and per animal-unit varied significantly among levels of grazing pressure. The efficiency of forage harvest varied linearly from $99 \%$ at $10 \mathrm{~kg} / \mathrm{au} /$ da grazing pressure to $53 \%$ at the $50 \mathrm{~kg} / \mathrm{au} / \mathrm{da}$ grazing pressure. Continued research is needed to define and explain the relationship between harvesting efficiency and grazing pressure further. This relationship needs to be quanti- fied further in light of the increasing usage of short duration grazing systems. Specifically, data are needed that look at stocking density and grazing pressure relationships. Optimum levels of grazing pressure for success of intensive short duration grazing systems, in terms of plant and animal response, are still not known.

\section{Literature Cited}

Barr, A.J., J.H. Goodnight, J.S. Sall, and J.T. Helwig. 1976. A user's guide to S.A.S. 76. SAS Institute, Inc., Raleigh, N. Carolina. 329 p.

Carter, J.F., D.W. Bolin, and D. Erickson. 1960. The evaluation of forages by agronomic "difference" method and the chromagen-chromic oxide "indicator" technique. N. Dakota Agr. Exp. Sta. Bull. No. 426.

Gordon, C.H., J.C. Derbyshire, C.W. Alexander, and D.E. McCloud. 1966. Effects of grazing pressure on the performance of dairy cattle and pastures. Proc. 10th Int. Grassld. Cong. 10:470-475.

Hewitt, G.B., W.H. Burleson, and J.A. Onsager. 1976. Forage losses caused by the grasshopper Aulocara ellotti on shortgrass rangeland. J. Range Manage. 29:376-380.

Kartchner, R.J., and L.R. Rittenhouse. 1979. A feces-urine separator for making total fecal collections from the female bovine. J. Range Manage. 32:404-405.

Kothmann, M.M., G.W. Mathis, P.T. Marion, and W.J. Waldrip. 1970. Livestock production and economic returns from grazing treatments on the Texas Experimental Ranch. Tex. Agr. Exp. Sta. Bull. 1100.

Laycock, W.A., H. Buchanan, and W.C. Krueger. 1972. Three methods of determining diet, utilization, and trampling damage on sheep ranges. $J$. Range Manage. 25:352-356.

McNaughton, S.J. 1979. Grazing as an optimization process: GrassUngulate relationships in the Serengeti. Amer. Natur. 113:691-703.

Pearson, H.A. 1975. Herbage disappearance and grazing capacity determinations of southern pine bluestem range. J. Range Manage. 28:71-73.

Savory, Alan, and Stan Parsons. 1980. The Savory grazing method. Beef Cattle Sci. Handbook. Vol. 17. Agriservices Foundation, Inc. p. 215-221.

Society for Range Management. 1974. A Glossary of terms used in range management. 2nd ed. $36 \mathrm{p}$.

Steel, R.G.D., and J.H. Torrie. 1960. Principles and procedures of statistics. McGraw-Hill Book Co. 481 p.

Tilley, J.M.A., and R.A. Terry. 1963. A two-stage technique for the in vitro digestion of forage crops. J. Brit. Grassld. Soc. 18:104-111.

Van Dyne, G.M., and J.H. Meyer. 1964. A method of measurement of forage intake of grazing livestock using mirco digestion techniques. J. Range Manage. 17:204-208.

Van Soest, P.J., and R.H. Wine. 1967. Use of detergents in the analysis of fibrous feeds. IV. Determinations of plant cell-wall constituents. J. Ass. Off. Agr. Chem. 50:50-55. 